Article

\title{
Communicative Acts Used by Emergent Trilingual Pupils in English Classrooms in the Basque Autonomous Community
}

\author{
Amaia Fernández, Pilar Sagasta and Nagore Ipiña *(D) \\ Faculty of Humanities and Educational Sciences, Mondragon Unibertsitatea, 20540 Eskoriatza, Spain \\ * Correspondence: nipina@mondragon.edu
}

Received: 13 May 2019; Accepted: 26 July 2019; Published: 30 July 2019

\begin{abstract}
This research aims at examining the communicative acts (CA) performed by Grade 5 emergent trilingual pupils in the Basque Autonomous Community (BAC) in northern Spain when interacting in the English classroom. Likewise, it examines translanguaging practices when performing CA to analyze whether pupils deploy similar linguistic resources (LR) regardless of the CA they enact. Moreover, it investigates whether pupils from different sociolinguistic contexts behave similarly. Preliminary results suggest that Grade 5 pupils taking part in this study enact CA related to inviting elaboration or reasoning, expressing or inviting ideas, guiding direction of dialogue or activity, positioning and coordination, and showing understanding by using LR coming from different linguistic systems (mostly English and Basque) when interacting in the English classroom across sociolinguistic areas.
\end{abstract}

Keywords: spontaneous translanguaging; discourse practices; language acquisition

\section{Introduction}

Translanguaging is a relatively new term that was first used by Cen Williams in 1994 in Wales concerning a pedagogical strategy observed in the Welsh classrooms. Baker (2011) defined translanguaging as a process to make meaning, shape experiences, acquire understanding and knowledge through the use of two languages, and Cenoz and Gorter (2017) drew the difference between pedagogical and spontaneous translanguaging. This paper focuses on spontaneous translanguaging and examines the discursive practices (Cenoz and Gorter 2017) of emergent trilinguals in the English classroom, because as Canagarajah (2011) states, research is needed to investigate how multilingual speakers combine codes in their discursive practices. Moreover, these trilingual pupils have three languages in the curriculum: Basque, Spanish, and English, and their schools are situated in two different sociolinguistic areas. Therefore, this paper considers the social context to better understand these pupils' discursive practices, because as Cenoz and Gorter (2019, p. 133) claim, "the social context is crucial when discussing translanguaging, particularly in communities that involved minority languages".

Cenoz and Gorter (2017) analyzed translanguaging in the context of minority regional languages and examined whether it could be a threat or an opportunity for minority languages. They state that spontaneous translanguaging is common practice in the case of bilingual speakers. Nevertheless, they claim that people involved in the maintenance of these regional languages may fear that their language will lose prominence and they advocate to soften borders between languages in a sustainable way. Linguistic separation, they assert (Cenoz and Gorter 2019), may have benefited minority languages in the past, but today that separation may be counterproductive, because as Gorter et al. (2014, p. 217) affirm, "Basque, Spanish and English reinforce each other". Five principles have been suggested 
by Cenoz and Gorter (2017) for promoting sustainable translanguaging in school contexts in which minority languages are used; creating breathing spaces for the minority language; fostering the use of the minority language in translanguaging practices; developing metalinguistic awareness through the use of the emergent multilinguals' entire linguistic repertoire; reinforcing language awareness; and linking spontaneous translanguaging to pedagogical tasks.

Nonetheless, as Otheguy and García $(2019$, p. 10) claim, educators who foster a translanguaging pedagogy realize that named languages are socio-cultural constructions; but they also recognize that "named languages do not correspond to a psycholinguistic reality of dual systems". That is, bilinguals have access to their whole linguistic repertoire in communicative situations in which the use of linguistic features is not restricted to named languages. On the contrary, bilinguals need to monitor the selection of linguistic features when the interlocutor does not share their linguistic repertoire, as in the case of a monolingual speaker, or in situations in which strict language separation is required. Hence, as Otheguy et al. $(2015$, p. 297) claim, translanguaging focuses on the individual, it views the speaker from the inside, whereas named languages adopt "the view from the outside".

Concerning research conducted on translanguaging, positive results have been highlighted as regards language learning opportunities and metalinguistic (Fuller 2015; St. John 2018; Rosiers 2018). Fuller (2015) examined the discursive practices of nine-year-old students enrolled in a German-English bilingual school placed in Berlin. She found that the children's choices to deploy bilingual discourse were personal choices with interactional motivations; when they played the role of good students, they used English, the language of the classroom. Nonetheless, they knew that German was the language of the wider community, and that its status as a symbol of youth culture was more powerful; so they often used it for creating solidarity with their classmates. St. John (2018) studied the multilingual interactions among subject teachers, newly arrived Somali pupils, and mother tongue tutors in oral examinations in Sweden, and found that translanguaging is a situated practice and language choice and its use depends on both the communicative situation and the participants' idiolects. Therefore, it should be analyzed within an interactional framework. Rosiers (2018) investigated the interactional engagement of primary pupils with their linguistic repertoire in two multilingual Belgian schools and claimed that translanguaging practices are influenced by factors such as the topic, the group, as well as cognitive and linguistic factors.

Considering all the above-mentioned studies, it is evident that further research is necessary to find out how emergent multilinguals use their linguistic repertoire in their classrooms, because as Wei (2015, p. 196) asserts, translanguaging can have an important impact on "the development of identity, social relationships and values amongst their users". Moreover, studies that examine spontaneous practices in classrooms where three languages are included in the curriculum, and one of them is a regional minority language are needed, and that is precisely the main goal of this study. This research aims at examining the communicative acts (CA) performed by emergent trilingual pupils in the BAC when interacting in the English classroom. Likewise, it examines translanguaging practices to study whether pupils deploy similar linguistic resources (LR) regardless of the CA they enact. Moreover, it investigates whether pupils from different sociolinguistic contexts behave similarly, because, as mentioned above, the social context may have an impact on translanguaging practices (Cenoz and Gorter 2019).

Regarding the aforementioned literature, this study raises the following questions:

1. Which CA do emergent trilingual pupils perform when communicating in the English classroom?

2. Do they use similar LR regardless of the CA being performed?

3. Does the sociolinguistic area make a difference?

\section{Materials and Methods}

The BAC is a bilingual community with Basque and Spanish as co-official languages and this study was conducted in two schools; School A located in Araba (Spanish sociolinguist area) and School $\mathrm{B}$ in Gipuzkoa (Basque sociolinguistic area). Both schools follow a D linguistic model, with Basque as 
the main language of instruction and Spanish and English taught as a subject. It must be clarified that this is part of an ongoing study we are carrying out with 153 Grade 5 pupils. Nonetheless, for the purpose of this study, fourteen pupils have been randomly selected, as depicted in Table 1.

Table 1. Participants.

\begin{tabular}{ccc}
\hline $\begin{array}{c}\text { School A } \\
\text { (Spanish Area) }\end{array}$ & \multicolumn{2}{c}{$\begin{array}{c}\text { School B } \\
\text { (Basque Area) }\end{array}$} \\
\hline & S1 & S19 \\
& S2 & S20 \\
& S3 & S21 \\
Grade 5 (n:6) & S4 & S22 \\
& S5 & S23 \\
& S6 & S24 \\
& & S25 \\
& & S26 \\
\hline \multicolumn{3}{c}{ Participants. }
\end{tabular}

Fourteen Grade 5 emergent trilingual pupils from two different sociolinguistic areas took part in this study. Six pupils were randomly selected in the Spanish sociolinguistic area and eight pupils in the Basque area.

All participants are Basque and Spanish bilinguals and English is an L3 and they all started learning English at the age of four. It is an ethnographic case study (Gay et al. 2006) in which these fourteen emergent trilingual pupils were observed in the English classroom during the school year 2016/2017, and their spontaneous interactions were audio-recorded. Altogether, $25 \mathrm{~h}$ and $48 \mathrm{~min}$ of study were analyzed; $13 \mathrm{~h}$ and $14 \mathrm{~min}$ in School A and $12 \mathrm{~h}$ and $33 \mathrm{~min}$ in School B.

Data collected were transcribed and analyzed using the SEDA scheme (Hennessy et al. 2016), which was previously adapted to take into account the particular context of study. This scheme is a tool used to examine the CA enacted in classroom dialogue, which are grouped into clusters according to the function of the act. A CA is defined by Hennessy et al. (2016, p. 20) as "the minimum number of utterances or actions needed to reflect its function".

Based on the research work conducted by these authors, the CA performed by the fourteen participants were identified. Subsequently, the CA were coded and clustered, taking into account the communicative function fulfilled. Afterwards, the translanguaging practices observed in the CA were detected and categorized following this code: LR1 (Basque); LR2 (Spanish); LR3 (English); LR4 (Basque/Spanish); LR5 (Basque/English); LR6 (Spanish/English); LR7 (Other/English); and LR8 (Basque/Spanish/English). Finally, data corresponding to each sociolinguistic area were detected and analyzed separately in order to compare and contrast the results.

\section{Results}

\subsection{Results Concerning Research Question One and Two}

Regarding the first research question, Grade 5 pupils articulated 4523 utterances and enacted 4365 CA, which were coded, clustered, and analyzed, as Table 2 shows.

Table 2 depicts that these participants mostly performed CA to focus the dialogue on key aspects of the activity (G5), $12 \%$. They also uttered CA to state (dis)agreement or position (P6), $11.1 \%$ or propose solution (P3), 11\%. Similarly, they enacted CA to ask for elaboration or clarification (I6), $9.8 \%$. 
Table 2. Performed communicative acts (CA).

\begin{tabular}{|c|c|c|c|c|}
\hline \multicolumn{3}{|r|}{ CA PERFORMED } & \multirow{2}{*}{ FREQUENCY } & \multirow{2}{*}{ PERCENTAGE } \\
\hline & Cluster & Interactional Function & & \\
\hline \multirow{6}{*}{ I } & \multirow{6}{*}{$\begin{array}{l}\text { Invite } \\
\text { elaboration or } \\
\text { reasoning }\end{array}$} & Ask for explanation or justification of another's contribution & 7 & $0.2 \%$ \\
\hline & & $\begin{array}{l}\text { Invite build on/elaboration/(Dis)agreement/evaluation of } \\
\text { another's contribution or view }\end{array}$ & 30 & $0.7 \%$ \\
\hline & & Invite possibility thinking based on another's contribution & 5 & $0.1 \%$ \\
\hline & & Ask for explanation or justification & 58 & $1.3 \%$ \\
\hline & & I5 Invite possibility thinking or prediction & 4 & $0.1 \%$ \\
\hline & & Ask for elaboration or clarification & 427 & $9.8 \%$ \\
\hline \multirow{4}{*}{$\mathrm{R}$} & \multirow{4}{*}{$\begin{array}{l}\text { Make } \\
\text { reasoning } \\
\text { explicit }\end{array}$} & Explain or justify another's contribution & 13 & $0.3 \%$ \\
\hline & & R2 Explain or justify own contribution & 17 & $0.4 \%$ \\
\hline & & Speculate or predict on the basis of another's contribution & 39 & $0.9 \%$ \\
\hline & & Speculate or predict & 72 & $1.6 \%$ \\
\hline \multirow{3}{*}{ B } & \multirow{3}{*}{ Build on ideas } & B1 Build on/Explain/clarify other's contribution & 72 & $1.6 \%$ \\
\hline & & Clarify/elaborate own contribution & 74 & $1.7 \%$ \\
\hline & & Synthesize ideas & 7 & $0.2 \%$ \\
\hline \multirow{2}{*}{$\mathrm{E}$} & \multirow{2}{*}{$\begin{array}{l}\text { Express or } \\
\text { invite ideas }\end{array}$} & Invite opinion/beliefs/ideas & 229 & $5.2 \%$ \\
\hline & & Make other (relevant) contribution & 279 & $6.4 \%$ \\
\hline \multirow{7}{*}{ G } & \multirow{7}{*}{$\begin{array}{c}\text { Guide direction } \\
\text { of dialogue or } \\
\text { activity }\end{array}$} & G1 Encourage dialogue & 56 & $1.3 \%$ \\
\hline & & G2 Propose action or activity & 237 & $5.4 \%$ \\
\hline & & Introduce authoritative perspective & 8 & $0.2 \%$ \\
\hline & & Provide informative feedback & 57 & $1.3 \%$ \\
\hline & & Focus the dialogue on key aspects of the activity (guiding) & 523 & $12.0 \%$ \\
\hline & & Allow thinking time & 4 & $0.1 \%$ \\
\hline & & organization of group activities & 201 & $4.6 \%$ \\
\hline \multirow{7}{*}{$\mathrm{P}$} & \multirow{7}{*}{$\begin{array}{l}\text { Positioning and } \\
\text { coordination }\end{array}$} & Synthesize ideas & 4 & $0.1 \%$ \\
\hline & & Compare/evaluate alternative views & 21 & $0.5 \%$ \\
\hline & & Propose solution & 480 & $11.0 \%$ \\
\hline & & Acknowledge shift in position & 1 & $0.0 \%$ \\
\hline & & Challenge viewpoint & 5 & $0.1 \%$ \\
\hline & & State (dis)agreement/position & 485 & $11.1 \%$ \\
\hline & & Gap of knowledge & 4 & $0.1 \%$ \\
\hline \multirow{4}{*}{$\mathrm{C}$} & \multirow{4}{*}{ Connect } & C1 Refer back to prior contributions & 1 & $0.0 \%$ \\
\hline & & Make learning trajectory explicit & 0 & $0.0 \%$ \\
\hline & & Link learning with other contexts & 0 & $0.0 \%$ \\
\hline & & Invite inquiry beyond the lesson & 0 & $0.0 \%$ \\
\hline \multirow{3}{*}{$\mathrm{RD}$} & \multirow{3}{*}{$\begin{array}{l}\text { Reflect on } \\
\text { dialogue or } \\
\text { activity }\end{array}$} & RD1 Talk about talk & 0 & $0.0 \%$ \\
\hline & & RD2 Reflect on learning process/purpose/value & 0 & $0.0 \%$ \\
\hline & & RD3 Invite reflection about process/purpose/value of learning & 0 & $0.0 \%$ \\
\hline \multirow{10}{*}{$\mathrm{EE}$} & \multirow{10}{*}{$\begin{array}{l}\text { Express } \\
\text { emotions }\end{array}$} & EE1 Happiness & 19 & $0.4 \%$ \\
\hline & & EE2 Excitement & 73 & $1.7 \%$ \\
\hline & & EE3 Gratitude & 7 & $0.2 \%$ \\
\hline & & EE4 Expectation/hope & 16 & $0.4 \%$ \\
\hline & & EE5 Astonishment & 81 & $1.9 \%$ \\
\hline & & EE6 Dubious & 43 & $1.0 \%$ \\
\hline & & EE7 Tedium & 18 & $0.4 \%$ \\
\hline & & EE8 Irritation & 26 & $0.6 \%$ \\
\hline & & EE9 Frustration & 78 & $1.8 \%$ \\
\hline & & EE10 Anger & 28 & $0.6 \%$ \\
\hline
\end{tabular}


Table 2. Cont.

\begin{tabular}{|c|c|c|c|}
\hline \multicolumn{2}{|r|}{ CA PERFORMED } & \multirow{2}{*}{ FREQUENCY } & \multirow{2}{*}{ PERCENTAGE } \\
\hline Cluster & Interactional Function & & \\
\hline & CU Check understanding & 78 & $1.8 \%$ \\
\hline & SU Show understanding & 227 & $5.2 \%$ \\
\hline & AH Ask for help & 39 & $0.9 \%$ \\
\hline & AP Ask for permission & 41 & $0.9 \%$ \\
\hline & Apr Ask for participation & 22 & $0.5 \%$ \\
\hline NRC & Non Relevant Contribution & 149 & $3.4 \%$ \\
\hline & TOTAL: & 4365 & $100 \%$ \\
\hline
\end{tabular}

Performed CA.

Concerning the second research question, Table 3 below displays the most common CA enacted by all the participants and the resources they used. It is evident that English resources (LR3) are by far the most common means used to perform the CA in the English classroom: I6 (208 utterances), E1 (89 utterances), E2 (138 utterances), G2 (63 utterances), G5 (333 utterances), G7 (52 utterances), P3 (374 utterances), P6 (271 utterances), and SU (158 utterances).

Table 3. Linguistic resources (LR) used in the most frequently performed CA.

\begin{tabular}{|c|c|c|c|c|c|c|c|c|c|c|c|c|}
\hline \multicolumn{4}{|c|}{ CA Performed } & \multicolumn{9}{|c|}{ LR Used } \\
\hline I & $\begin{array}{l}\text { Invite } \\
\text { elaboration or } \\
\text { reasoning }\end{array}$ & I6 & Ask for elaboration or clarification & 104 & 19 & 208 & 22 & 30 & 28 & 0 & 9 & 7 \\
\hline E & $\begin{array}{l}\text { Express or invite } \\
\text { ideas }\end{array}$ & E1 & Invite opinion/beliefs/ideas & 44 & 31 & 89 & 24 & 17 & 20 & 0 & 2 & 2 \\
\hline \multirow[t]{2}{*}{ G } & \multirow{2}{*}{$\begin{array}{l}\text { Guide direction } \\
\text { of dialogue or } \\
\text { activity }\end{array}$} & G5 & $\begin{array}{l}\text { Focus the dialogue on key aspects of } \\
\text { the activity (guiding) }\end{array}$ & 49 & 18 & 333 & 28 & 28 & 52 & 0 & 9 & 6 \\
\hline & & G7 & Organization of group activities & 68 & 16 & 52 & 34 & 12 & 16 & 0 & 2 & 0 \\
\hline $\mathrm{P}$ & $\begin{array}{l}\text { Positioning and } \\
\text { coordination }\end{array}$ & P3 & Propose solution & 25 & 15 & 374 & 7 & 17 & 33 & 0 & 6 & 3 \\
\hline
\end{tabular}

LR used in the most frequently performed CA.

Nonetheless, Basque resources (LR1) were used more often than English resources (LR3) to propose action or activity (G2), 77 utterances. Basque means were also frequently observed when participants asked for elaboration or clarification (I6), 104 utterances or stated (dis)agreement/position (P6), 101 utterance, although they frequently used English means for those CA. When showing understanding (SU), even though they deployed English means (LR3) more often, Spanish resources (LR2) were frequently observed, 26 utterances. Participants also made use of Spanish and English resources (LR6) when focusing the dialogue on key aspects of the activity (G5), 52 utterances, or when proposing a solution (P3), 33 utterances, although the use of English was predominant. Finally, the number of Basque, Spanish, and English means (LR8) were rather low, but they were observed in eight out of nine most frequent CA: I6 (9 utterances), E1 (2 utterances), E2 (5 utterances), G2 (10 utterances), G5 (9 utterances), G7 (2 utterances), P3 (6 utterances), P6 (2 utterances).

Here is a sample interaction (Table 4) to exemplify the aforementioned CA performed and the use of LR: 
Table 4. Sample interaction.

\begin{tabular}{lcc}
\hline 26. S3-Then pour, ze pour da botatzea [because pour means spill] & P3 & LR5 \\
27. S1-Eta gero [and then]? & I6 & LR1 \\
28. S3-Take one:.:. & P3 & LR3 \\
A ver [let's see], ... the monkeys ... coma, daisy's petal, no daisy's petal no ... & P3 & LR6 \\
29. S-And ... & E2 & LR8 \\
30. S1-Y ponemos [and we write ] and, and. Bai zer da koma bat::.:[Yes because it is a comma] & P3 & LR6 \\
31. S2-A ver [Let's see ] ... all the monkeys ... . On a spoon ... venga [come on]! on a spoon & G3 & LR6 \\
Spoon, he dicho [I said], spoon ... on a spoon, comma, two centiliters, comma ... & I6 & LR3 \\
32. S1-E two centilits [centilitres] of & P3 & LR3 \\
33. S2-Spoon! & P6 & LR5 \\
34. S1-Bai [yes], spoon. & B2 & LR6 \\
Two centilits [centilitres] ... dos centilitros [two centilitres]. &
\end{tabular}

Sample interaction.

\subsection{Results Concerning Research Question Three}

In order to analyze the impact sociolinguistic area could have on the performance of $\mathrm{CA}$, utterances from each area were identified: 2408 in School A and 2115 in School B. A total amount of 2318 CA in School A and 1970 in School B were detected, coded, and clustered. Table 5 below displays a summary of the most frequently enacted CA in each sociolinguistic area:

Table 5. Most frequently performed CA in each sociolinguistic area.

\begin{tabular}{|c|c|c|c|c|c|}
\hline \multicolumn{6}{|c|}{ CA Performed in School A } \\
\hline \multicolumn{2}{|r|}{ Cluster } & \multicolumn{2}{|r|}{ Interactional Function } & \multirow{2}{*}{$\begin{array}{c}\text { Frequency } \\
226\end{array}$} & \multirow{2}{*}{$\begin{array}{c}\text { Percentage } \\
9.7 \%\end{array}$} \\
\hline I & $\begin{array}{l}\text { Invite elaboration or } \\
\text { reasoning }\end{array}$ & I6 & Ask for elaboration or clarification & & \\
\hline \multirow{2}{*}{ G } & \multirow{2}{*}{$\begin{array}{l}\text { Guide direction of } \\
\text { dialogue or activity }\end{array}$} & G2 & Propose action or activity & 141 & $6.1 \%$ \\
\hline & & G5 & $\begin{array}{c}\text { Focus the dialogue on key aspects } \\
\text { of the activity (guiding) }\end{array}$ & 263 & $11.3 \%$ \\
\hline \multirow{2}{*}{$\mathrm{P}$} & \multirow{2}{*}{$\begin{array}{l}\text { Positioning and } \\
\text { coordination }\end{array}$} & P3 & Propose solution & 263 & $11.3 \%$ \\
\hline & & P6 & State (dis)agreement/position & 223 & $9.6 \%$ \\
\hline \multicolumn{6}{|c|}{ CA performed in School B } \\
\hline I & $\begin{array}{l}\text { Invite elaboration or } \\
\text { reasoning }\end{array}$ & I6 & Ask for elaboration or clarification & 201 & $10.2 \%$ \\
\hline $\mathrm{E}$ & $\begin{array}{l}\text { Express or invite } \\
\text { ideas }\end{array}$ & E2 & Make other (relevant) contribution & 182 & $9.2 \%$ \\
\hline G & $\begin{array}{l}\text { Guide direction of } \\
\text { dialogue or activity }\end{array}$ & G5 & $\begin{array}{c}\text { Focus the dialogue on key aspects } \\
\text { of the activity (guiding) }\end{array}$ & 260 & $13.2 \%$ \\
\hline \multirow{2}{*}{$\mathrm{P}$} & \multirow{2}{*}{$\begin{array}{l}\text { Positioning and } \\
\text { coordination }\end{array}$} & P3 & Propose solution & 217 & $11 \%$ \\
\hline & & P6 & State (dis)agreement/position & 262 & $13.3 \%$ \\
\hline
\end{tabular}

Most frequently performed CA in each sociolinguistic area.

Results show that participants in both sociolinguistic areas performed similar CA when interacting in the English classroom. However, in the Spanish sociolinguist area (School A), participants mostly enacted CA to focus the dialogue on key aspects of the activity (G5), $11.3 \%$, or to propose solutions (P3), $11.3 \%$. Nonetheless, pupils from the Basque sociolinguistic area (School B) enacted more CA to make contributions (E2), 9.2\%. The frequency was also higher in School B when enacting CA to state (dis)agreement/position (P6), 13.3\%, or focusing the dialogue on key aspect of the activity (G5), $13.2 \%$. Therefore, the impact of the sociolinguistic area cannot be confirmed. 
Concerning LR identified when performing the five most frequent CA, Table 6 below depicts that participants in the Spanish sociolinguistic area mostly used English resources (LR3), except for proposing actions or activity (G2), CA which were pupils frequently performed in Basque (LR1). Nonetheless, pupils from the Basque sociolinguistic area mostly deployed English resources (LR3) in the enacted five CA. However, it can also be observed that the use of Basque resources (LR1) in both areas is more frequent than the use of Spanish ones (LR2), even in the Spanish sociolinguistic area. Therefore, the impact of the sociolinguistic area cannot be confirmed.

Table 6. LR used in the most frequently performed CA in each sociolinguistic area.

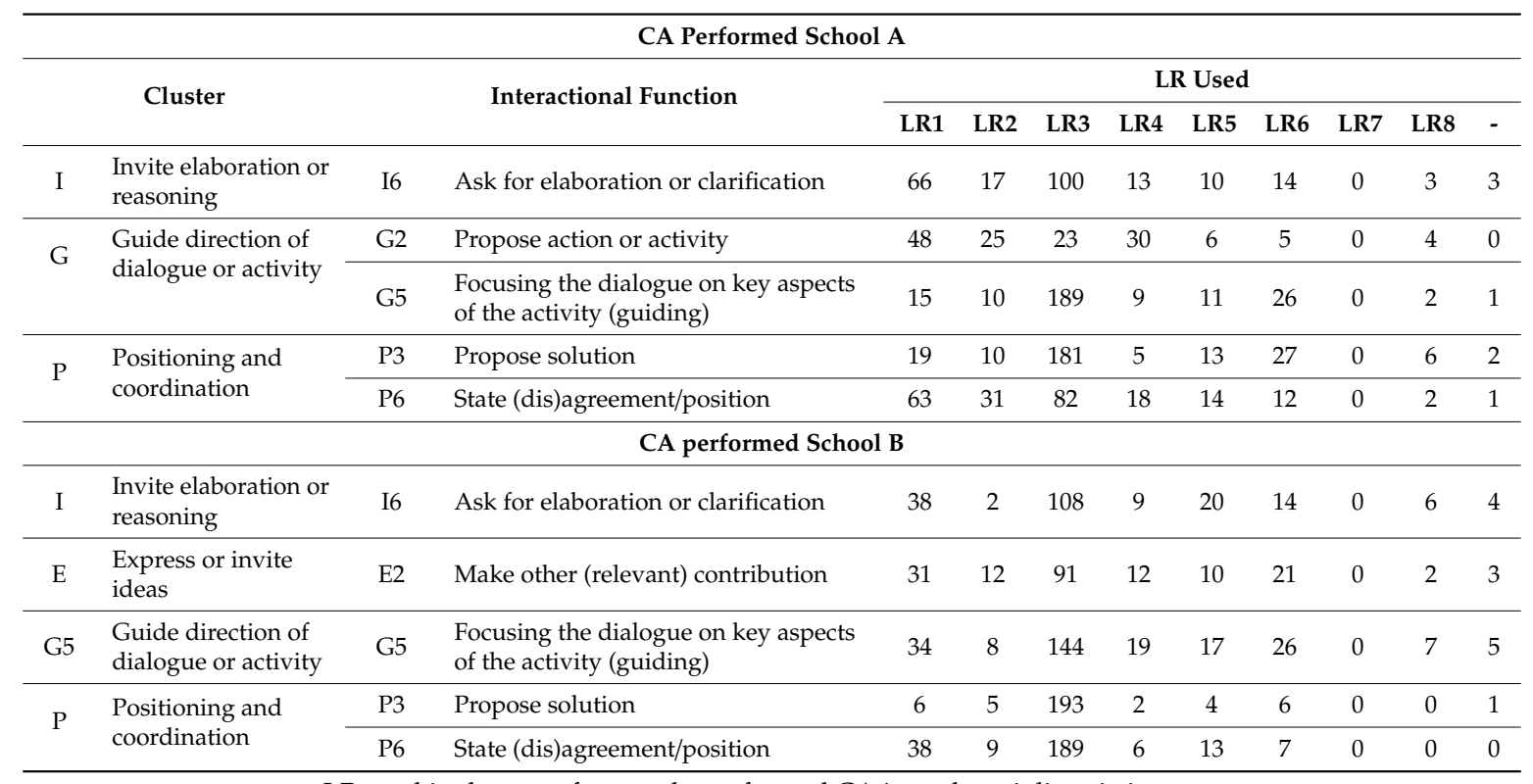

LR used in the most frequently performed CA in each sociolinguistic area.

Here are two sample interactions (Tables 7 and 8 ) to exemplify the aforementioned use of CA and the LR deployed:

Table 7. Example from School A.

\begin{tabular}{|c|c|c|}
\hline $\begin{array}{l}\text { 340. S3-Zuek jaten badituzue txuriak... niri eman una de cada ... porque si no yo me quedo sin txuri. } \\
\text { [If you it the white ones... give one of each ... because the other way I won't have white] }\end{array}$ & P3 & LR4 \\
\hline 341. S1-Si uno no come... [If one of us don't eat... ] & G5 & LR2 \\
\hline 342. S2-A ver ... nahastu behar ditugu ... [let's see ... we have to mix them] & G7 & LR4 \\
\hline 343. S3-Zuek jan behar dituzue hau eta hau... [you have to eat this and this] & G5 & LR1 \\
\hline $\begin{array}{l}\text { 344. S1-A ver ... bat jaten } d u \ldots \text { bi hau, a ver, bi jaten } d u \text { bi con leche ... eta [Let's see } \ldots \text { you eat } \\
\text { one } . . . \text { second this. Let's see ... she eats two with milk ... and] one, one. }\end{array}$ & G7 & LR8 \\
\hline $\begin{array}{l}\text { 345. S3-A ver, zuk jango duzu hau eta Maiderrek hau ... Orduan nik ez dudanez jaten txuria. [Let's } \\
\text { see, you will eat this and Maider this... So, as I don't eat White... . ] }\end{array}$ & G7 & LR4 \\
\hline 346. S2-Nik ez dut jaten [I don't eat] black. & E1 & LR5 \\
\hline $\begin{array}{l}\text { 347. S3-Pues hori ... nik ez dudanez jaten txuria, eman behar didazue bat de [So that ... as I don't } \\
\text { eat White, you have to give me a piece of] black ... - }\end{array}$ & G2 & LR8 \\
\hline
\end{tabular}


Table 8. Example from School B.

\begin{tabular}{|c|c|c|}
\hline 201. S26-And the cauldron we?-.-No ... & I6 & LR3 \\
\hline 202. S19- ... and put it in the caldron ... & P3 & LR3 \\
\hline 203. S22-Pour it $e z$ [no]! & P6 & LR5 \\
\hline 204. S20-Zer eingo deu [what are we going to do]? & I6 & LR1 \\
\hline 205. S22-Simmer and mix with ... & P3 & LR3 \\
\hline 206. S21-Simmer?-The ingredients are into the caldron. & I6 & LR3 \\
\hline 207. S22-And simmer it-Punto [dot]. Meanwhile ... -Meanwhile ... & P3 & LR5 \\
\hline 208. S20-A ver [let's see] ... in daikeu [we can do] ... Mix together in a bowl ... a dragon head ... & G5 & LR8 \\
\hline 209. S19- ... and a bit of ... & P3 & LR3 \\
\hline 210. S22-Jarri daikeu [we can put] dry ... & P3 & LR5 \\
\hline 211. S20-Mix together ... mix together. & P3 & LR3 \\
\hline 212. S19-TH, T, H, E[in Basque] & E2 & LR1 \\
\hline 213. S22-R & E2 & LR3 \\
\hline
\end{tabular}

Example from School B.

\section{Discussion}

The aim of the present study was twofold: on the one hand, to examine the communicative acts (CA) performed and the linguistic resources (LR) used by Grade 5 emergent trilingual pupils in the BAC while interacting in the English classroom. Also, on the other hand, to investigate the possible impact the sociolinguist area could have on the use of linguistic resources.

Addressing our first research question, the analysis suggests that participants in this study mostly performed CA concerning inviting elaboration or reasoning, expressing or inviting ideas, guiding direction of dialogue or activity, positioning and coordination, and showing understanding. All these CA are closely related to the type of activities performed in the English classroom and the patterns of interaction involved in such activities. Looking at our classroom data and observations carried out throughout the academic year 2016/2017, it can be said that the pupils had plenty of opportunities for meaningful interaction with their peers due to the great amount of activities done in groups, small groups, and whole class activities in which pupils needed to organize themselves, negotiate meaning, and take a stance in order to perform the task. This pedagogical approach seems to be suitable in order to observe the translanguaging practices of these emergent trilinguals, as can be seen in the following paragraph. As Otheguy and García (2019) state, bilinguals, in this case emergent trilinguals, have access to their whole linguistic repertoire in communicative situations in which the use of linguistic features is not restricted to named languages. These were exactly the communicative situations created in the English classroom. Rosiers (2018) and St. John (2018) also found that translanguaging practices should be analyzed in an interactional framework, because factors such as communicative situations, the topic, the group, as well as cognitive and linguistic features, may impact such practices.

Turning to the second research question, it was observed that pupils used similar linguistic resources (LR) regardless of the communicative acts (CA) being performed. These emergent trilinguals deployed English resources (LR3) more often than Basque (LR1) or Spanish ones (LR2) in the English classroom. Likewise, as reported by other researchers concerning bilingual students (Baker 2011; Cenoz 2017; García 2017; García-Mateus and Palmer 2017; Lewis et al. 2012), participants in the study frequently used linguistic resources coming from two systems, in this study, Basque and Spanish, in order to make meaning, share ideas, acquire understanding, and knowledge. Hence, this study confirms that spontaneous translanguaging is common practice in bilingual speakers, in our case, emergent trilingual speakers, as Cenoz and Gorter (2017) affirm. Equally, it reinforces the idea put forward by Wei (2015, p. 180), in the sense that translanguaging is not merely a combination of linguistic structures, "but also a creative strategy by the language user".

Results also showed that participants tended to deploy resources from Basque when they asked for elaboration or clarification, stated (dis)agreement or position, or when they proposed an action or activity. It seems that due to the status of Basque in both schools, as it is the main language of 
instruction, participants could have acquired more resources in that language than the ones developed in Spanish or English. Likewise, these emergent trilingual pupils deployed Spanish means (LR2) more often than Basque ones (LR1) when showing understanding, focusing the dialogue on key aspects of the activity, or when they proposed a solution. This tendency may be related to the fact that Basque is the main language of instruction in both schools, and Spanish and English are taught as subjects. Nonetheless, further research is needed to find out the possible impact of individual differences. It may well be that the home language of these emergent trilingual pupils and the use of Basque and Spanish resources in the different language domains have an impact on the use of their whole linguistic repertoire.

Finally, concerning the third and last research question, a comparison between both sociolinguistic areas suggest that pupils from both schools performed similar CA related to inviting elaboration or reasoning, guiding direction of dialogue or activity, and positioning and coordination. However, in the Basque sociolinguistic area, CA related to expressing or inviting ideas are also frequent. Our finding also reveals that the use of linguistic resources (LR) was similar in both sociolinguist areas. It seems that the possible impact of the sociolinguist area in the translanguaging practices of these Grade 5 emergent trilingual pupils cannot be confirmed. This could be due to the fact that the main language of instruction in both schools is Basque. In addition, the use of the same material during the English lessons could have an impact in the CA enacted by participants in both areas, as they followed the same methodology and they had similar classroom and task organization. Nevertheless, as aforementioned, individual differences should be analyzed to fine-tune these results.

Given the limited size of our sample, it is evident that further research is needed to study how these emergent trilingual pupils in the BAC communicate spontaneously to make themselves understood in the English classroom over the academic year. The present study is only an exploratory study in which fourteen pupils from two different sociolinguistic areas were randomly selected, observed, and recorded, with the aim of examining the enacted CA and LR used in the English classroom. In that line, the ongoing longitudinal study we are conducting will help us contribute to this field of research. As researchers such as Lewis et al. (2012) claim, a sociolinguistic approach is also needed in this field of research. Equally, Cenoz and Gorter (2017) highlight the possible impact of the social context when studying translanguaging practices.

Author Contributions: Conceptualization, A.F. and P.S.; Investigation, A.F.; Methodology, A.F., P.S., and N.I.; Formal Analysis, A.F. and N.I.; Data curation, A.F.; Writing original draft and presentation, A.F.; Writing, review and editing, A.F., P.S., and N.I.

Funding: This research received no external funding.

Conflicts of Interest: The authors declare no conflict of interest.

\section{References}

Baker, Colin. 2011. Language development and language allocation in bilingual education. In Foundations of Bilingual Education and Bilingualism, 3rd ed. Clevedon: Multilingual Matters LTD, pp. 269-94.

Canagarajah, Suresh. 2011. Translanguaging in the Classroom: Emerging Issues for Research and Pedagogy. Applied Linguistics Review 2: 1-28.

Cenoz, Jasone. 2017. Translanguaging in school contexts: International perspectives. Journal of Language, Identity E Education 16: 193-98. [CrossRef]

Cenoz, Jasone, and Durk Gorter. 2017. Minority languages and sustainable translanguaging: Threat or opportunity? Journal of Multilingual and Multicultural Development. [CrossRef]

Cenoz, Jasone, and Durk Gorter. 2019. Multilingualism, translanguaging, and minority languages in SLA. The Modern Language Journal 103. [CrossRef]

Fuller, Janet M. 2015. Language choices and ideology in the bilingual classroom. In Multilingual Education: Between Language Learning and Translanguaging. Cambridge: Cambridge University Press, pp. 137-58. ISBN 978-1-107-47751-3. 
García, Ofelia. 2017. Translanguaging in Schools: Subiendo y Bajando, Bajando y Subiendo as Afterword. Journal of Language, Identity E Education 16: 256-63.

García-Mateus, Suzanne, and Deborah Palmer. 2017. Translanguaging Pedagogies for Positive Identities in Two-Way Dual Language Bilingual Education. Journal of Language, Identity E Education 16: 245-55.

Gay, Lorraine R., Mills Geoffrey, and Airasian Peter. 2006. Educational Research: Competencies for Analysis and Applications. New York: Pearson Merrill Prentice Hall.

Gorter, Durk, Victoria Zenotz, and Jasone Cenoz. 2014. Multilingualism and European minority languages: The case of Basque. In Minoriy Languages and Multilingual Education. Dordrecht: Springer Science + Business Media, pp. 201-20. ISBN 978-94-007-7316-5.

Hennessy, Sara, Sylvia Rojas-Drummond, Rupert Higham, Ana María Márquez, Fiona Maine, Rosa María Ríos, Rocío García-Carrión, Omar Torreblanca, and María JoséBarrera. 2016. Developing coding scheme for classroom dialogue across educational contexts. Learning, Culture and Social Interaction 9: 16-44. [CrossRef]

Lewis, Gwyn, Bryn Jones, and Colin Baker. 2012. Translanguaging: Origins and development from school to street and beyond. Educational Research and Evaluation: An International Journal on Theory and Practice 18: 641-54. [CrossRef]

Otheguy, Ricardo, and Ofelia García. 2019. Plurilingualism and translanguaging: Commonalities and divergences. International Journal of Bilingual Education and Bilingualism. [CrossRef]

Otheguy, Ricardo, Ofelia García, and Wallis Reid. 2015. Clarifying translanguaging and deconstructing named languages: A new perspective from linguistics. Applied Linguistics Review 6: 281-307. [CrossRef]

Rosiers, Kirsten. 2018. Translanguaging revisited Challenges for research, policy and pedagogy based on an inquiry in two Belgian classrooms. In Translation and Translanguaging in Multilingual Contexts. Amsterdam: John Benjamins Publishing Company, pp. 361-83. [CrossRef]

St. John, Oliver. 2018. Between question and answer Mother tongue tutoring and translanguaging as dialogic action. In Translation and Translanguaging in Multilingual Contexts. Amsterdam: John Benjamins Publishing Company, pp. 334-60. [CrossRef]

Wei, Li. 2015. Complementary classrooms for multilingual minority ethnic children as a translanguaging space. In Multilingual Education: Between Language Learning and Translanguaging. Cambridge: Cambridge University Press, pp. 177-98. ISBN 978-1-107-47751-3.

(C) 2019 by the authors. Licensee MDPI, Basel, Switzerland. This article is an open access article distributed under the terms and conditions of the Creative Commons Attribution (CC BY) license (http://creativecommons.org/licenses/by/4.0/). 